\title{
The Importance of Control Variable in Policy Implementation Model of Smith's Theory
}

\author{
Dr. Syahrani, Msi \\ Department of Public Administration Mulawarman University, Indonesia
}

\begin{abstract}
Whether control variable is more important than the capability of the implementers is still a debate among the experts. In Smith's theory, which represents bottom-up approach, the capability of the implementers has a higher score than the control variable, while in Sabatier and Mazmanian's theory, which represents the top-down approach, the control variable has a higher score. To know about this issue, the writer discussed it in the research findings entitled "The implementation of Village Fund Allocation (VFA) Program in Kutai Kartanegara District."

This research aims to analyze 1) the roles of control variable and the forms of control in the implementation of Village Fund Allocation Program in Kutai Kartanegara District. 2) The roles of the capability, honesty as well as the commitment of the implementers.

This research applied qualitative method. The data were collected through depth interview, documentation and observation. The data were analyzed by using interactive model of data analysis from Miles and Huberman.

The research finding showed that 1) in implementing Village Fund Allocation Program, a control is required because it can prevent the dishonesty of the implementers. Every form of deviation can be corrected so that the implementation of VFA Program can run well. The control can be in the form of internal and external control. 2). the capability of the implementers is also very important because having sufficient capability will help them to implement the VFA Program effectively. The commitment of the implementers is found to be fairly high but their honesty is still low.

All of the evidence proved that the two variables are very important for the implementation of one program; therefore, it is recommended that control variable is importantly required in the policy implementation model of Smith's theory to make the policy implementation successful.
\end{abstract}

Keywords: Control Variable, the capability of the implementers, Smith's Model of Policy Implementation, VFA (Village Fund Allocation) Program

\section{Introduction}

The characteristic of the implementation of VFA program is the implementation of a policy which applies bottom up (Parson, 1997: 463) in Putra, 2003 : 85). The VFA Program requires the community to actively involve, starting from planning, implementation, evaluation and maintenance (The Principles of VFA according to The Government Regulation No. 27 Year 2005). This is one characteristic of the bottom-up approach.

One of the theories which applies bottom-up approach is Smith's Theory. Smith $(1983: 202-205)$ sees the policy implementation as a social change:

"In order to develop a model of the policy implementation process, it is essential to view the policy process from the point of view of social and political change. Governmental policies are designed to induce changes in society."

Furthermore, Smith (1983:197) states:

"Policy implementation is seen as a tension generating force in society. Tensions are generated between and within four components of the implementing process: idealized policy, implementing organization, target group, and environmental factors."

The following is the Model of Policy Implementation constructed by Smith: 
Fig 1 : Smith's Model of Policy Implementation

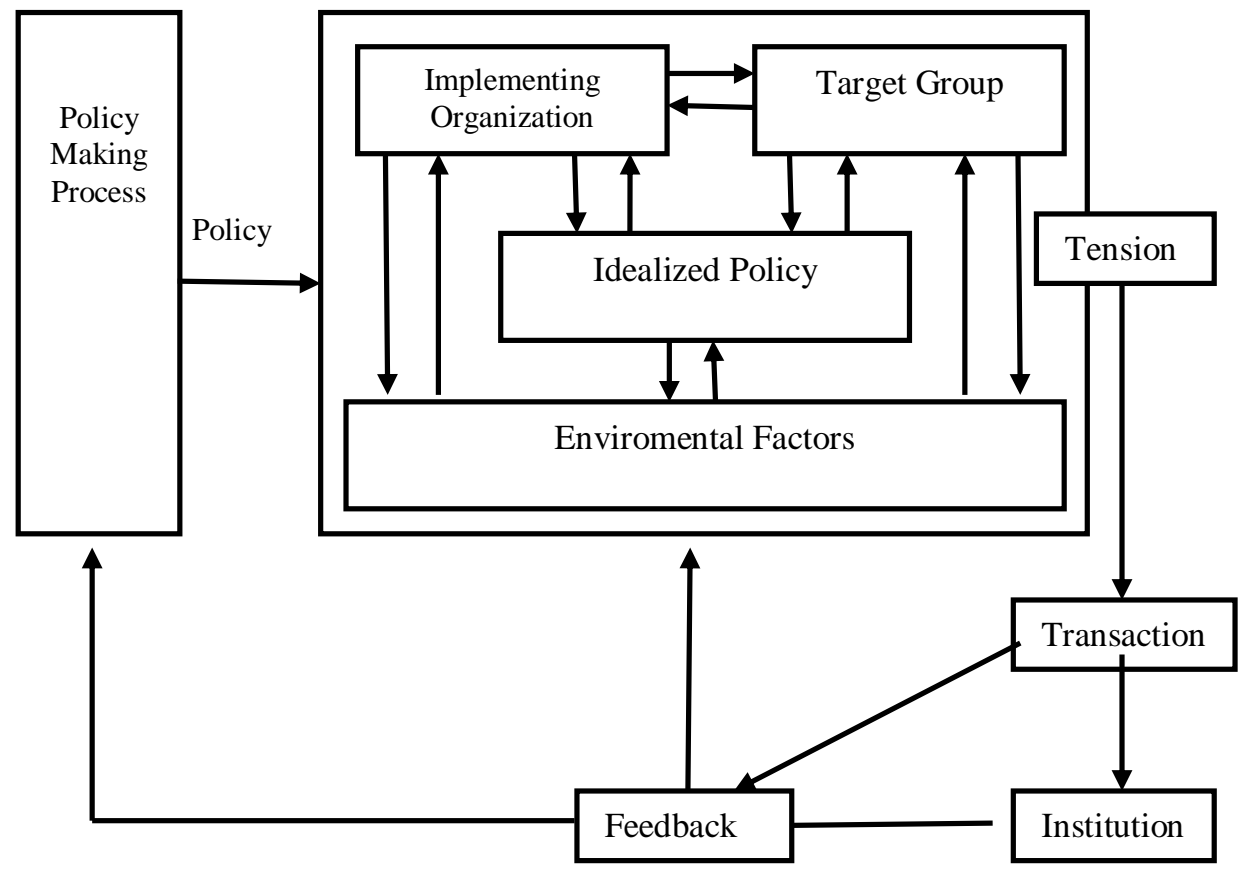

Source : Smith, $(1983 ; 203)$

The application of Smith's theory in this research is based on the relevance between the facts in the field and the characteristics of the implementation of VFA program which has 4 (four) variables as stated in Smith's theory as follows:

1. Idealized policy: the empowerment of human resources, environment and economic

2. Target Group: poor people, marginal groups, etc.

3. Implementing organization: village offices

4. Environmental Factors: social, cultural, and economic conditions of the community

The above four variables are not independent, but rather they are in an unity and influence and interact to each other so that they often create tensions which lead to the occurrence of transactions or negotiations between formulators and policy implementers, resulting in ideal programs to be implemented (Smith 1983 : 203).

Transaction process occurs when pra musrembang and musrembangdes are conducted. In the transaction process, it is possible to establish organizations/institutions as the technical implementation units (Karang Taruna, Irma, PKK Group, Farmer Group etc.) (Smith ,1983:197).

The application of Smith's theory is very appropriate because the four variables are found in the implementation of the VFA Program.

In the Smith's Model above, according to Putra (2001, 92), it gives a high score on the realism and on the capability of the implementers. This model sees that the policy implementation does not work linearly or mechanistically, but it opens an opportunity to make transactions through negotiation process or bargaining to create a compromise with a target group dimension.

Putra's statement is in line with Parson's statement (2008:470-471) who stated that bottom-up approach gives an emphasis on the importance of facts in the field (realism), where the implementation in the field gives a freedom to apply the policy. Professionals (the capability of the implementers) play important roles in giving a guarantee to the implementation of a policy.

Therefore, Smith's $(1983 ; 205)$ said that this model will work effectively if the implementing organizations have the capacity to implement it. This is in line with the opinions from C. Shabbir Cheema and Dennis A. Rondinelli (in Nawawi, 2009; 194) who stated that the performance of the policy implementation is very much dependent on the characteristics and capability of the implementing units, which include technical skills and the politics. This is termed by Grindle as competent and capable policy implementers (in Nawawi, 2009: 143).

On the contrary, the model of policy implementation proposed by Sabatier and Mazmanian gives a low score on the important proofs or realism and the capability of the implementers. This model considers that the policy implementation may work mechanically or linearly. Therefore, it gives an emphasis on effective coordination and control and ignores humans as the target group as well as the roles of other actors (Mazmanian and Paul Sabatier (1988) in Putra, 2009; 90). 
The same opinion is also given by Hjern (in Ekowati, 2009 : 128) who stated that in doing their jobs the top-downers are more preoccupied with the problems of how to control the activities of street level bureaucrats or man on the street from any possibilities of disturbing the policy that has been formulated.

The importance of control is also supported by Hogwood and Lewis (1986) who stated that the implementation of a program needs to be controlled to assure that it runs smoothly. C. Shabbir Cheema and Dennis A Rondinelli (in Nawawi, 2009; 194), stated that one of the four variables that can influence performance and has an impact on a program when it is implemented, especially the centralized government program, is the need for control on the use of budget resources.

The question is that which one is more important, is it the capability of implementers or control variable ? According to the writer, these are equally important because the two variables can affect the successfulnes of a policy implementation. The implementation of a program will be effective if it is supported by sufficient human resources and if it is supervised to prevent any deviation.

In light of the theories and assumptions above, it is found that this research is not only based on Smith's point of view but also supported by other supporting theories. Elmore (in Hill and Hupe, $2006: 58$ ) stated: "in the study of complicated events, it can be valuable to triangulate accounts, using different theoretical models, to try to achieve a satisfactory explanation of what happened ". Then Sabatier (in Hill, 1993: 282) argues :

"The top down approach is more useful for making these preliminary assessments because of its greater theoretical development. The identification of specific variables and causal relationships makes predictions possible. On the other hand the bottom up approach has not yet developed much of a substantive theory and thus is poorly equipped to make predictions".

Hill and Hupe (2006:56) furthermore say "the debate between the top-down and bottom-up perspectives moved on to effort to synthesize the approaches, picking out key ideas from each".

Village Fund Allocation Program is self-managed so that this condition makes it possible for the implementers to misuse the funds. This phenomenon is found in the site http;//www.bongkar.co.id/news/26law/1686-menekan-penyimpangan-add.html (Wednesday, 06 July 2011 ) with the heading "Menekan Penyimpangan ADD (Reducing the Deviations of VFA)" :

"Village Fund Allocation provided by the district governments for village development is often siphoned by irresponsible officials of the beneficiary designated villages, either through their budget management or accountability reports."

On the other hand, the phenomena relating to the low capability of the human resources in implementing the VFA program are proposed by the Head of the Community and Village Government Empowerment Board of Kutai Kartanegara District, H Hairil Anwar SH MHum MH, who states that:

"Of 185 villages only 54 villages in 7 Sub-districts received full parts of the VFA program in 2010. The remaining village received one, two or three parts only; and even, there was one village which did not receive any part of the FVA just like what happened in Sambera Baru Village in Marangkayu Subdistrict. How does it happen? There are a lot of factors that make the VFA not fully received by the villages. The main factor is related to the preparation of accountability report. It is the responsibility of the village secretary, assisted by the Village Head and other officials, to prepare the accountability report. If the capability of human resources, in this case the village secretary, is not as much as it is required, or even below the standard, then it is certainly that the preparation of the accountability report will not be accomplished. (Source: http://bappeda.kutaikartanegarakab.go.id /berita.php?id=215)"

In light of the debates and the problems above, the writer tries to review his own research findings entitled: "The Implementation of Village Fund Allocation (VFA) in Kutai Kartanegara District"

\section{Methodology}

The reasearch method used is a qualitative approach. This approach is used in order to obtain deep and comprehensive descriptions concerning implementation of Village Fund Allocation (VFA) program in Kutai Kartanegara Regency. The research location was done in the area of Kutai Kartanegara Regency which covering the subdistricts of Upstream, midlle and coastal zone. To obtain the data needed, the researcher used three techniques of data collection, namely

- in-depth interview : conduct in-depth interviews with several key informants such as the head office of Bapemas (Community Empowerment Board), the village chief, the head of the LPM ( Institute for Community Empowerment), heads and members of BPD (Village Consultative Body) and Chairman RT.

- Documentation: the collection of secondary data such as reports, archives, research and the like.

- Participant observation; make observations on various social events or situations that relate to the problem or research focus 
The data was analyzed using interactive models as proposed by Miles and Huberman (1992), this model consists of three components, namely data reduction analysis, presentation of data and conclusion.

Fig.3 Interactive model

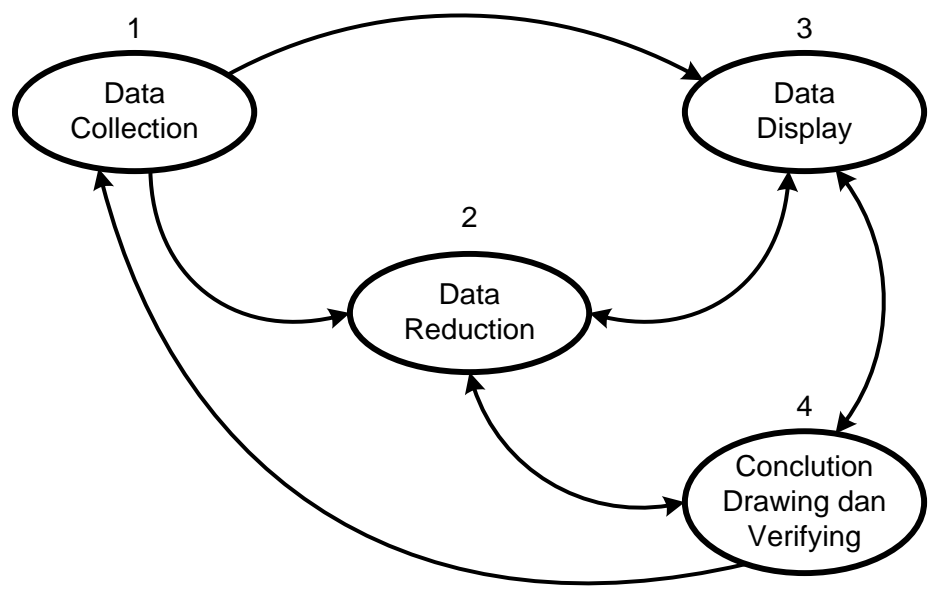

source: Miles dan Huberman ( 1992; 20)

Data reduction: The data collected is reduced and summarized in a way chosen subject matters, which are not relevant discarded, focused on the things that are important. Then sifting through data based on unit concepts, themes, and certain categories that will provide a sharper picture of the observations and facilitate researchers to seek additional data if needed

Presentation of data: All data presented in the form of narrative text, charts and relationship to allow for the temporary conclusion

Conclusion: Interpretation of the data was conducted to obtain a deeper meaning and wider on the results of the research being done, by noting regularities, patterns, explanations, possible configurations, causal flow and propositions.

The data was analyzed repeatedly and continuously as interactive models in the time before, during and after data collection in order to obtain a conclusion about which one is more important the ability of implementers or control variable in the implementation of VFA program

\section{A. Control Variable}

\section{Research Findings}

\section{a). Control Mechanism in VFA Activity}

In implementing the VFA program, there are some controlling institutions involved, such as Village Consultative Body, known as BPD or Badan Permusyawaratan Desa, Assistantship Team of Sub-district Level, District Inspectorate, and social control. stated :

BPD performs its control function before and during the activities. The Village Secretary of Loh Sumber

"BPD conducts the supervision in the field, the location of the activities. If the activities have followed the Budget Plan, then "the official report of the supervision" is signed. On the contrary, if the activities do not follow the Budget Plan (e.g. the volume of the activity is different from the budget plan), then the volume needs to be adapted before the "official report of the supervision" is signed" (Interview, S. 3-62014).

There are some deviations found by BPD, for example, there is a mismatch between VFA activities and the work order agreement and the activities proposed in musrembang (Rural Development Plan Meeting) are different from the programs proposed in pre-musrenbang (pre Development Plan Meeting). All of the deviations are reported to the Village Chief for further correction.

Asssistanship Team at Sub-district level conducts the supervision during the activities of VFA and at the end of the activities. This team verifies the accountability documents of the implementation and do monitoring in the fields. When a deviation is found, this team reports it to the Village Chief for further correction.

The district inspectorate is a technical institution which serves as a supporting element for the district government in the field of supervision. This inspectorate conducts an audit of the implementation of VFA 
program at the end of the fiscal year. The audit covers the use of budget, the completeness of the administrative documents and the implementation of the activities. The following are some findings of the inspectorate:

Table 1: Examples of examination findings of the inspectorate, 2012

\begin{tabular}{|c|c|c|}
\hline No & Examination Results & Recommendation \\
\hline 1. & $\begin{array}{l}\text { village Treasurer... } \\
\text { Object Details }\end{array}$ & $\begin{array}{l}\text { Ordered village treasurer to immediately work on the details of } \\
\text { the } \quad \text { object } \\
\text { corresponding }\end{array}$ \\
\hline 2. & $\begin{array}{l}\text { Income Tax Article } 21 \text { of } \mathrm{Rp} . . . . . . \text { has not } \\
\text { been withheld and remitted to the state } \\
\text { treasury yet }\end{array}$ & $\begin{array}{l}\text { Ordered village Treasurer... The next year the tax payment on } \\
\text { time and in accordance with applicable regulations }\end{array}$ \\
\hline 3. & $\begin{array}{l}\text { expenditure of } \mathrm{Rp} . . . . \text { has not been equipped } \\
\text { with a complete and valid evidence }\end{array}$ & $\begin{array}{l}\text { Ordered Village Treasurer... the following year any expenditure } \\
\text { of funds must be equipped with a complete evidence and } \\
\text { legitimate }\end{array}$ \\
\hline 4. & $\begin{array}{l}\text { There is a self-managed activities that are } \\
\text { not equipped with the SPK (Work Letter } \\
\text { Agreement) }\end{array}$ & $\begin{array}{l}\text { village head is recommended that each self-managed activities } \\
\text { always make an agreement that includes rights and obligations } \\
\text { as well as implementing activities to include a clause about the } \\
\text { involvement of local communities in implementing activities }\end{array}$ \\
\hline 5. & $\begin{array}{l}\text { There is a difference between the } \\
\text { expenditure of Rp ........... which was } \\
\text { recorded at the Bend } 20 \text { the number of } \\
\text { supporting memorandum (memorandum } \\
\text { real) }\end{array}$ & $\begin{array}{l}\text { In order for the village treasurer depositing excess cash back to } \\
\text { the village treasury }\end{array}$ \\
\hline 6. & $\begin{array}{l}\text { There is a shortage of jobs for physical } \\
\text { development activities fiscal year } 2011 \\
\text { amounting to } \mathrm{Rp} \text {........ }\end{array}$ & $\begin{array}{l}\text { Village treasurer to deposit back the excess money to the village } \\
\text { treasury. } \mathrm{Rp} \text {............... }\end{array}$ \\
\hline 7. & $\begin{array}{l}\text { Village treasurer ..... has not make Ledger } \\
\text { Object Details Spending, yet }\end{array}$ & $\begin{array}{l}\text { Village treasurer to immediately work Spending Payment } \\
\text { Request Document in accordance legislation }\end{array}$ \\
\hline 8. & $\begin{array}{l}\text { Income Tax (Income Tax) section } 21 \text { of } \mathrm{Rp} \\
\ldots \ldots . \text { for ADD in } 2009 \text { has not been } \\
\text { collected and deposited into the state } \\
\text { treasury }\end{array}$ & $\begin{array}{l}\text { Village treasurer to immediately deposit the income tax article } \\
21 \text { amounting to } \mathrm{Rp} \text {.......... into the state treasury in accordance } \\
\text { with the laws and proof of payment delivered to the Inspectorate }\end{array}$ \\
\hline 9. & $\begin{array}{l}\text { Shortage of Work for the ADD Physical } \\
\text { development activities in } 2011 \text { budget Rp } \\
\text {.............. }\end{array}$ & $\begin{array}{l}\text { It is recommended to village heads in the next fiscal year before } \\
\text { composing RAB (Budget Plan) for each activity should be } \\
\text { conducted physical inspections in the field first so that there is } \\
\text { no change in the RAB for each of the above activities as well as } \\
\text { the shortage of jobs transferred to other workers }\end{array}$ \\
\hline 10. & 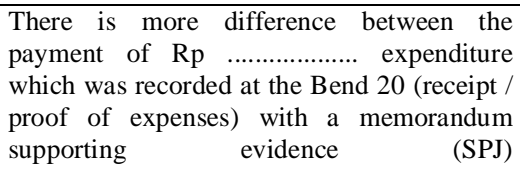 & $\begin{array}{l}\text { Ordered village treasurer and executive order to deposit the } \\
\text { excess money back } \mathrm{Rp} . . . . . . . . \text { to the village treasury }\end{array}$ \\
\hline 11. & $\begin{array}{l}\text { There is a shortage of jobs for the } \\
\text { manufacture of bridges ..... RT } \ldots \text { R... Village } \\
\begin{array}{lccr}\text {.... } & \text { worth } & \text { Rp } & \ldots . .\end{array}\end{array}$ & $\begin{array}{l}\text { advised Village chief to immediately deposit the excess funds } \\
\text { back due to lack of work worth } \mathrm{Rp} . . . \ldots \ldots \ldots . . .\end{array}$ \\
\hline 12. & $\begin{array}{l}\text { There is wastage of funds worth } \mathrm{Rp} . . . . . . \text { on } \\
\text { the activity of repair / rehabilitation of } \\
\text { village ............. }\end{array}$ & $\begin{array}{l}\text { Suggested village head in the rehabilitation must conduct any } \\
\text { repairs before inspecting physical building in the field }\end{array}$ \\
\hline 13. & and others...................... & \\
\hline
\end{tabular}

Source: Report of Examination (LHP) Inspectorate, 2012

Some findings of the District Inspectorate included the incompleteness of the administration of the reports and receipts; the mismatch between the physical implementation and the Work Order Agreement (SPK) and the difference in the budget use. Those cases were found in almost every village with 3 to 4 cases, while there were two cases which were brought to court in 2010.

In addition to the above control, the community also conducts control over the VFA program. The community may give information if there are some irregularities found in the implementation of VFA program by reporting them to the BPD or Village Chief. The Secretary of Rempanga Village said:

"people have the right to give information when they found irregularities in the VFA activities and they can directly report the irregularities to BPD and the Village Chief or they may present them in the village meeting". (interview, I, $11-6-2014$ ).

\section{b). The Forms of Control}

The control or supervision conducted by the Village Consultative Body or BPD ( Badan Permusyawaratan Desa) is an external control. BPD is the village legislative body that controls the village chief policies because the village chief has "discretion" in making policies in the village government level. In Article 1 Paragraph 12 of the Village Government Regulation, it is stated: 
The village budget which is abbreviated "APB Desa" (Revenue and Expenditure Budget of Village) is the annual financial plan of the village government which is jointly prepared and approved by the Village Government and BPD, stipulated through Village Regulation.

Then in Article 1, Paragraph 14, it is also stated: Village Regulation is a law that is made jointly by BPD and Village Chief.

In the technical guidelines of VFA Management, it is stated that the jobs of BPD as a supervisor include:

a. Routinely controlling the implementation of every activity according to the schedule;

b. Assuring that the implementation and the outcome of the activities have been suitable with the work order agreement.

c. The problems related to the financial administration is not the authority of the Supervision:

d. Together with village facilitators, signing the official report of the supervision result.

Then, the assistantship team in the sub-district level conducts the control at the time the VFA activities are taking place. If the assistantship team at the sub-district level found any irregularities in the VFA activities, then the irregularities will be reported to the village chief, then the village chief invites the technical implementers to correct them. This is a preventive form of control because this control tries to detect one aspect of VFA ongoing activities. If a problem is found in the aspect of an activity, then the activity should be corrected before the other activities are taking place. The Chief of Manunggal Jaya Village said: Assistantship team conducts physical and administrative control". (interview, W, 23-4-2014)

The control conducted by the District Inspectorate is in the form of feedback control because the district inspectorate conducts an audit of all VFA activities that have been accomplished at the end of fiscal year. The purpose of auditing is to determine the level of appropriateness of the activities with the standards and the objectives of the program. The inspectorate tries to find out whether all VFA activities have been appropriate with the standards and the objectives of the program or not. All of the irregularities found by the Inspectorate are corrected by the village chief as the feedback to evaluate the upcoming activities.

Therefore, there are three forms of control for VFA program, namely initial control, ongoing control, and feedback control.

\section{B. Variable of Capability of The Implementers}

a). The Capability of the Implementers

Based on data that have been collected, the capability of village officials who serve as the implementers of VFA program activities can be illustrated as follows:

Table 2: Number of village Officials according to educational level

\begin{tabular}{|c|c|c|c|c|c|c|c|c|c|c|c|c|c|}
\hline No & Subdistrict & $\begin{array}{c}\text { Num } \\
\text { ber } \\
\text { of } \\
\text { Villa }\end{array}$ & \multicolumn{10}{|c|}{$\begin{array}{l}\text { level of Education } \\
\text { Village Officials }\end{array}$} & \multirow[t]{2}{*}{ Total } \\
\hline & \multicolumn{12}{|c|}{ Coastal Zone } & \\
\hline & & & \multicolumn{2}{|c|}{ Bechelor } & \multicolumn{2}{|c|}{ Diploma } & \multicolumn{2}{|c|}{ High school } & \multicolumn{2}{|c|}{ Yunior } & \multicolumn{2}{|c|}{$\begin{array}{l}\text { primary } \\
\text { school }\end{array}$} & \\
\hline & & & $\begin{array}{c}\text { Numb } \\
\text { er }\end{array}$ & $\%$ & $\begin{array}{c}\text { Numb } \\
\text { er }\end{array}$ & $\%$ & $\begin{array}{c}\text { Numb } \\
\text { er }\end{array}$ & $\%$ & $\begin{array}{c}\text { Numb } \\
\text { er }\end{array}$ & $\%$ & $\begin{array}{c}\text { Numb } \\
\text { er }\end{array}$ & $\%$ & \\
\hline 1 & Samboja & 4 & 0 & 0,00 & 0 & 0,00 & 12 & 6,56 & 8 & 4,37 & 0 & 0,00 & 20 \\
\hline 2 & Muara Jawa & 0 & 0 & 0,00 & 0 & 0,00 & 0 & 0,00 & 0 & 0,00 & 0 & 0,00 & 0 \\
\hline 3 & Sanga-Sanga & 0 & 0 & 0,00 & 0 & 0,00 & 0 & 0,00 & 0 & 0,00 & 0 & 0,00 & 0 \\
\hline 4 & Anggana & 8 & 1 & 0,55 & 0 & 0,00 & 23 & 12,57 & 11 & 6,01 & 6 & 3,28 & 41 \\
\hline 5 & Muara Badak & 13 & 9 & 4,92 & 5 & 2,73 & 37 & 20,22 & 8 & 4,37 & 5 & 2,73 & 64 \\
\hline \multirow[t]{3}{*}{6} & Marang Kayu & 11 & 6 & 3,28 & 1 & 0,55 & 25 & 13,66 & 10 & 5,46 & 16 & 8,74 & 58 \\
\hline & Total & 36 & 16 & 8,74 & 6 & 3,28 & 97 & 53,01 & 37 & 20,22 & 27 & 14,75 & 183 \\
\hline & \multicolumn{12}{|c|}{ Middle Zone } & \\
\hline 1 & $\begin{array}{l}\text { Tenggarong } \\
\text { Seberang }\end{array}$ & 18 & 1 & 0,33 & 1 & 0,33 & 69 & 22,77 & 20 & 6,60 & 14 & 4,62 & 105 \\
\hline 2 & Tenggarong & 1 & 0 & 0 & 0 & 0 & 2 & 0,66 & 1 & 0,33 & 2 & 0,66 & 5 \\
\hline 3 & Loa Kulu & 12 & 3 & 0,99 & 2 & 0,66 & 38 & 12,54 & 12 & 3,96 & 13 & 4,29 & 68 \\
\hline 4 & Sebulu & 13 & 5 & 1,65 & 0 & 0 & 44 & 14,52 & 12 & 3,96 & 14 & 4,62 & 75 \\
\hline \multirow[t]{3}{*}{5} & Loa Janan & 8 & 3 & 0,99 & 3 & 0,99 & 23 & 7,591 & 16 & 5,28 & 5 & 1,65 & 50 \\
\hline & Total & 52 & 12 & 3,96 & 6 & 1,98 & 176 & 58,09 & 61 & 20,13 & 48 & 15,84 & 303 \\
\hline & \multicolumn{12}{|c|}{ Upstream zone } & \\
\hline
\end{tabular}


The Importance of Control Variable in Policy Implementation Model of Smith's Theory

\begin{tabular}{|l|l|c|c|c|c|c|c|c|c|c|c|c|c|}
1 & Muara Muntai & 13 & 6 & 1,14 & 1 & 0,19 & 32 & 6,08 & 18 & 3,42 & 9 & 1,71 & 66 \\
\hline 2 & Muara Wis & 7 & 0 & 0 & 0 & 0 & 15 & 2,85 & 7 & 1,33 & 13 & 2,47 & 35 \\
\hline 3 & Kota Bangun & 20 & 3 & 0,57 & 2 & 0,38 & 51 & 9,69 & 33 & 6,27 & 34 & 6,46 & 123 \\
\hline 4 & Muara Kaman & 19 & 2 & 0,38 & 1 & 0,19 & 33 & 6,27 & 29 & 5,51 & 36 & 6,84 & 101 \\
\hline 5 & Kenohan & 8 & 0 & 0 & 0 & 0 & 7 & 1,33 & 15 & 2,85 & 18 & 3,42 & 40 \\
\hline 6 & Kembang Janggut & 11 & 4 & 0,76 & 0 & 0 & 28 & 5,32 & 21 & 3,99 & 14 & 2,66 & 67 \\
\hline 7 & Tabang & 19 & 0 & 0 & 0 & 0 & 17 & 3,23 & 4 & 0,76 & 73 & 13,88 & 94 \\
\hline & Total & 97 & 15 & 2,85 & 4 & 0,76 & 183 & 34,7 & 127 & 24,14 & 197 & 37,45 & 526 \\
\hline
\end{tabular}

Source: Bapemas District Kukar, 2013

The data showed that the highest level of education that the village officials have is senior high school, approximately $45.06 \%$, followed by elementary school, approximately $26.88 \%$ and the last is junior high school, approximately $22.23 \%$. Then, based on region zones, the village officials with senior high school education level occupy middle zone more than those who occupy other zones. There is about $58.09 \%$ in the middle zone, $53.1 \%$ in the coastal zone and $34.79 \%$ in the upstream zone. The village officials with elementary school education level are mostly found in the upstream zone, approximately $37,45 \%$, in the middle zone $15,84 \%$ and in the coastal zone $14,75 \%$. In general, it can be said that the village officials still have low level of education.

While the empowerment program conducted by the Community Empowerment Board (Bappemas) of Kutai Kartanegara District can be described as follows:

Table 3 . The empowerment programs conducted by the Community Empowerment Board (Bappemas) of Kutai Kartanegara District

\begin{tabular}{|c|c|c|c|}
\hline No & \multicolumn{3}{|c|}{2011} \\
\hline 1. & Provision of Financial Administration Services & 15. & Documenting Asset and Village Wealth \\
\hline 2. & Provision of Office Stationery & 16. & screening candidates village head \\
\hline 3. & Provision Reading Material and Legislation & 17. & Preparation Expansion / Village Inauguration \\
\hline 4. & $\begin{array}{l}\text { Technical guidance on drafting legislation and } \\
\text { administration to the village }\end{array}$ & 18. & $\begin{array}{l}\text { Facilitation issues in the field of rural and village } \\
\text { government }\end{array}$ \\
\hline 5. & Provision of Technical Administrative Services & 19. & Implementation of Election and Inauguration of BPD \\
\hline 6. & Procurement Association of Regional Regulations & 20. & $\begin{array}{l}\text { Monitoring and evaluation of government performance } \\
\text { (BPD) }\end{array}$ \\
\hline 7. & $\begin{array}{l}\text { Increasing Professionalism For SEA appartur and } \\
\text { Village Government }\end{array}$ & 21. & Assistance for Distribution of village Apparatus allowance \\
\hline 8. & Procurement Office Building Equipment & 22. & Election and Inauguration of Village Head \\
\hline 9. & Rehabilitation Office Building & 23. & Rating Head of the village who excel \\
\hline 10. & Procurement of special garments & 24. & Preparation of Data Base for villages officials \\
\hline 11. & $\begin{array}{l}\text { Education and Training for the secretary of the } \\
\text { village (village secretary) were appointed as civil } \\
\text { servants to stage II and III }\end{array}$ & 25. & $\begin{array}{l}\text { Technical guidance on financial management village } \\
\text { Government Unit (VGU) society empowerment Agency } \\
\text { (SEA) and the village administration (VA) }\end{array}$ \\
\hline 12. & Preparation of Financial Reporting end of year & 26. & $\begin{array}{l}\text { Monitoring Preparation accountability report, ILPPD \& LPJ } \\
\text { Village head }\end{array}$ \\
\hline 13. & $\begin{array}{l}\text { Preparation of the Prognosis } \\
\text { Budget Reporting }\end{array}$ & 27. & Technical Guidance for BPD in the district of Kukar \\
\hline 14. & Development of Personnel Administration & 28. & and so on \\
\hline No & \multicolumn{3}{|l|}{ 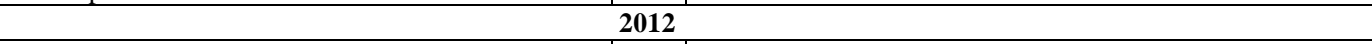 } \\
\hline 1. & Operational Training (latop) for Rural Governance & 15. & $\begin{array}{l}\text { Facilitation for the Establishment of integrated services } \\
\text { Postal District / Sub-District }\end{array}$ \\
\hline 2. & $\begin{array}{l}\text { Monitoring and Evaluation Capacity Building } \\
\text { Programme for Rural Governance }\end{array}$ & 16. & $\begin{array}{l}\text { Monitoring, Evaluation and Reporting Productive Economic } \\
\text { Business and Institutional Rural Economy }\end{array}$ \\
\hline 3. & $\begin{array}{l}\text { Facilitating Establishment of Customary Village } \\
\text { (Continued) }\end{array}$ & 17. & $\begin{array}{l}\text { Monitoring and Development KPM Village / Village } \\
\text { (Continued) }\end{array}$ \\
\hline 4. & Legal Products Training for village officials & 18. & $\begin{array}{l}\text { Monitoring and Evaluation Institute of Indigenous Village } \\
\text { (Continued) }\end{array}$ \\
\hline 5. & $\begin{array}{l}\text { Monitoring and Development of Rural Financial } \\
\text { Management }\end{array}$ & 19. & $\begin{array}{l}\text { Training candidates for Community Empowerment (KPM) } \\
\text { (Continued) }\end{array}$ \\
\hline 6. & $\begin{array}{l}\text { Training Village Self-management and Intensive } \\
\text { Self-management for PPTK }\end{array}$ & 20. & $\begin{array}{l}\text { Providing Education and Technical Training for Volunteers } \\
\text { IHC }\end{array}$ \\
\hline 7. & $\begin{array}{l}\text { Amendment Regulations on village Financial } \\
\text { Management and AFV }\end{array}$ & 21. & $\begin{array}{l}\text { Implementation of Rural Community's Information } \\
\text { Dissemination }\end{array}$ \\
\hline 8. & $\begin{array}{l}\text { Socialization on Criteria, Indicators and } \\
\text { Mechanisms for Independent Village }\end{array}$ & 22. & $\begin{array}{l}\text { Management Skills Training for village-owned enterprises } \\
\text { (BUMDes) }\end{array}$ \\
\hline 9. & $\begin{array}{l}\text { Monitoring and Evaluation for Independent Village } \\
\text { Activity }\end{array}$ & 23. & Institutional strengthening for Posyantekdes and Wartekdes \\
\hline 10. & Institutional Technical Guidance for Community & 24. & Administration and accountability of Rural Finance for Sub \\
\hline
\end{tabular}




\begin{tabular}{|r|l|r|l|}
\hline & Empowerment (LPM) & & District Assistance Team \\
\hline 11. & $\begin{array}{l}\text { Guidance for Community-Based Rural } \\
\text { Development Regions (PKPBM) }\end{array}$ & 25. & Revised Regulations on the village BUMDes No. 1 of 2008 \\
\hline 12. & $\begin{array}{l}\text { Training Facilities and Infrastructure Management } \\
\text { on Rural Clean Water }\end{array}$ & 27. & $\begin{array}{l}\text { Fdentification, Inventory and Verification onVillage Market } \\
\text { and LKM }\end{array}$ \\
\hline 13. & Documenting Asset and Wealth Village & 28. & and so on \\
\hline 14. & Implementation TTG Contest for District Level & \\
\hline
\end{tabular}

Source: Bappemas District Kukar, 2013

The fact that the village officials have low capability becomes a reason why some particular villages do not receive the VFA of part II and III. The incapability of the village officials in preparing the accountability report on one part of the VFA program prevents the villages to get the other parts of the VFA.

\section{b). The Honesty and Commitment of the Implementers}

The Government of Kutai Kartanegara District has a high commitment in implementing VFA program; therefore, the amount of VFA is consistently increasing every year.

Table 5: The amount of VFA funds from 2010 up to 2012

\begin{tabular}{|l|c|c|}
\hline Year & VFA Funds & Percentage \\
\hline 2010 & $187,655,421,898.00$ & 100 \\
\hline 2011 & $234,389,500,667.00$ & 124.90 \\
\hline 2012 & $232,211,973,517.00$ & 123.74 \\
\hline
\end{tabular}

Source: compiled from reports of Regents (LPJ), 2013

Based on the data above, the amount of VFA has been increasing significantly in the last two years. If the starting point of the VFA program was in 2010, then the amount of VFA in 2011 increased significantly, namely $24.90 \%$ and in 2012 it increased up to $23.74 \%$.

The commitment of the implementers is also high. This is indicated by the enthusiasm of the technical institutions to obtain and to implement the VFA program. The village governments as the implementing organizations also have a high motivation and consistency in implementing the VFA program in order to develop their own villages.

However, in relation to the honesty of the implementers, in 2010 there were 2 cases of village chiefs that were brought to court.

The result of audit conducted by the District Inspectorate both toward village officials and technical implementing organizations showed that the implementers performed some acts of dishonesty. The acts of dishonesty were found in every village and every year there were 3 to 4 cases that were reported incorrect and incomplete. Therefore, the inspectorate recommended to do some corrections on the report such as the correction related to the difference in the use of the funds, wasteful use of funds in VFA activities, the differences between the amount spent and the amount recorded on the Bend-20 receipts as well as in the supporting proof documents (accountability statements), the unaccomplished construction of a bridge, unaccomplished physical development of the VFA activities in the fiscal year of 2009 and so forth.

\section{Discussion of The Research Findings}

\section{A. Control Variable}

\section{a). Control Mechanism in VFA Activities}

Ripley et. al. (1973:10 in Ekowati, 2009: 64) stated that one factor that affects the capability of the implementing organizations is the level of hierarchical control over the sub-unit policies and the process in implementers' policies. Hogwood and Lewis, (1986) stated that in implementing one program, a control is needed to assure that the program runs smoothly.

BPD as the legislative institution in the village government has an equal position with the village government. BPD conducts a control over the VFA program activities not only at the time when the program is taking place but also at the time when the VFA program is being prepared in the Pre-musrenbang (pre Development Plan Meeting) and in the Musrenbangdes (Rural Development Plan Meeting). BPD then comes across with some findings which include the fact that the implementation and the outcome of the VFA activities do not match with the Work Order Agreement, and the program proposal prepared in the musrembang is not suitable with the proposal prepared in pre-musrenbang. All of BPD's findings are reported to the village chief for further correction. The purpose of this control is more anticipative by detecting the potential problems and taking necessary actions before a difficulty occurs.

The assistantship team at Sub-district level conducts controls when the VFA activities are going to be finished by verifying the accountability documents and by checking in the field to see whether RAB 
(Expenditure Budget Plan) is suitable with the reported activities (the completeness of the administrative documents). The control conducted by the assistantship team is an internal control because it is a part of the subdistrict government institution assigned to make sure that the activities take place according to the regulations or the given guideline. The nature of the control is preventive. The problems found by the assistantship team are directly reported to the village chief for further follow-up.

The district Inspectorate is a technical institution and serves as a supporting element of the district government in the field of Supervision. The Inspectorate conducts an audit at the end of the fiscal year with regard to financial expenditure, the completeness of administrative documents and the implementation of VFA activities. The control mechanism performed by the district inspectorate is more vertical. When the irregularities are found, the inspectorate gives a recommendation to the village government to make corrections and if these irregularities are not followed-up and they become BPK's findings, then, the cases will be brought to court.

The community also conducts controls over the VFA activities through a variety of ways such as having village meetings, opinion group meetings, and so on. The findings, accompanied by suggestions or advice, are reported to the village chief. Community's control is preventive and repressive. The Monitoring mechanism can be described as follows:

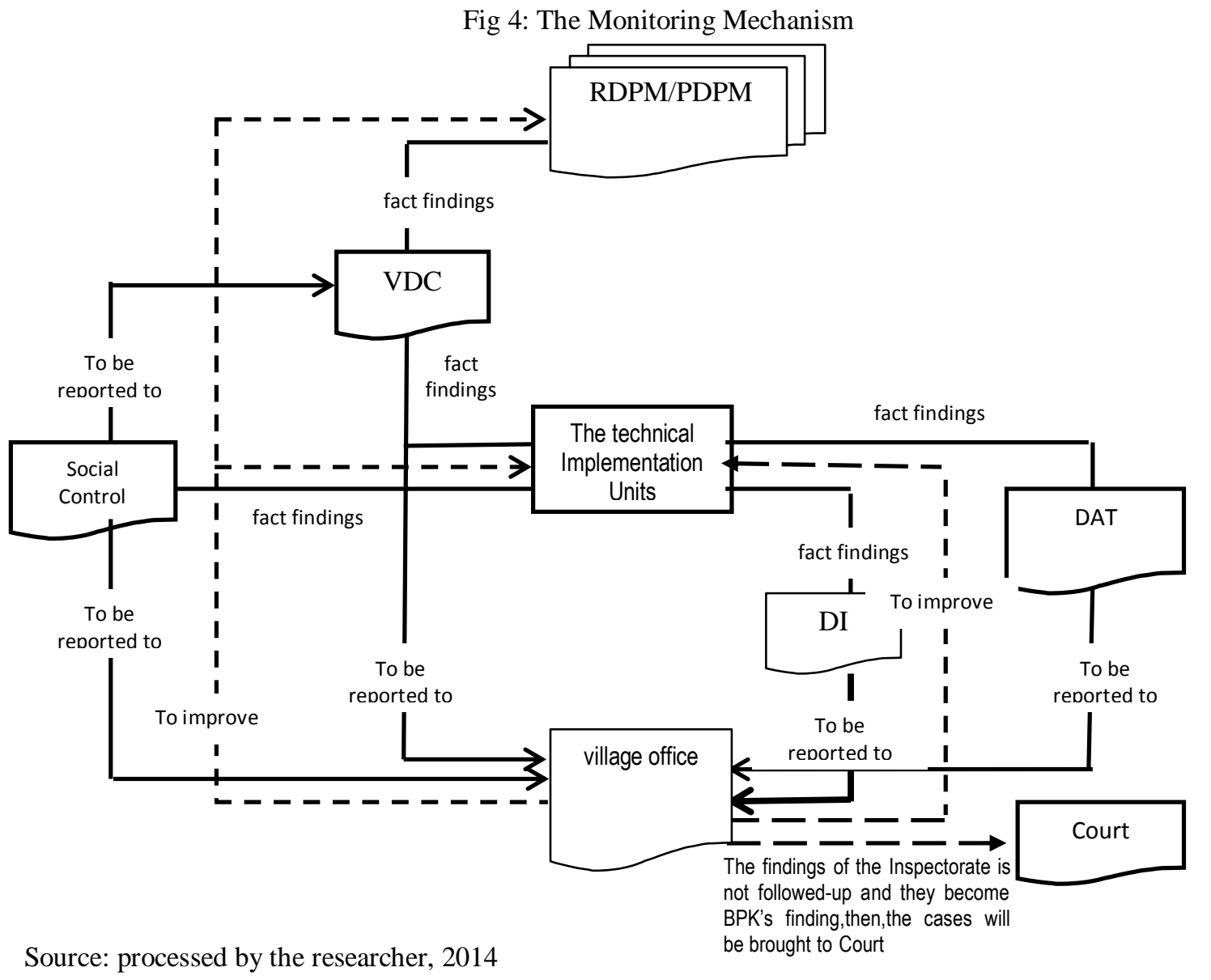
RDPM/PDPM : Rural (Pre) Development Plan Meeting
VCD : Village Consultative Body
DI : The District Inspectorat
DAT : The District Assistance Team

\section{b). The Forms of Control}

Seen from the position of control institutions, the forms of control conducted by the district assistantship team and the district inspectorate are internal controls because the controls are conducted by the institutions which are still the organizational units within the district government of Kutai Kartanegara. On the other hand, the controls conducted by the BPD and community are the form of external controls because the controls are conducted by the institutions outside the organizational units of the district government and they do not have any official relations with the units being supervised. The controls conducted are not subject to condition made by the village chief being supervised. Soekanto $(2010: 1)$ stated that viewed from the position of the controlling institutions/boards and the positions of the controlled institutions/boards, the forms of control can be divided 
into internal and external controls. Internal controls are the controls conducted by the institutions which have structural or organizational relations with the organizations within the government. On the contrary, external controls refer to the controls conducted by the organizations or institutions which do not have organizational or structural relations with the government.

\section{B. Variable of Capability of The Implementers a). Implementer Capability}

The relationship between the capability of implementers and the effectiveness of the implementation is supported by George C Edward III (1980; 10-11) who said that "if the personnel responsible for carrying out policies lack the resources to do an effective job, implementation will not be effective". Meter and Horn (in Hill and Hupe, 2008;46) stated that in implementing a policy, it is essential to have supporting resources, both human resouces and material resources. Brinkerhoff $(2001 ; 163)$ stated: "Policies must have both support and resources if they are to be succesfully implemented". Ripley et al (1973:10) in Ekowati, 2009: 64) stated that some of the aspects that influence the characteristics of the implementing organizations include the competence and the number of staffs.

The data above illustrated that the educational levels of the implementer are still low. Based on table 4, the empowerment program provided by the Community Empowerment Board of Kutai Kartanegara District Government for both village officials and technical instittutions is considered sufficient but the program gives more emphasis on administration than on the development of people's productive economy which is extremely needed by the target groups.

Edward III (1980;61) stats : "it is not enough for there to carry out to be an adequaete number of implementators to carry out a policy. Implementors must posses the skill necessary for that job at hand".

\section{b). The Honesty and Commitment of the Implementers}

High level of honesty and commitment of the implementers can affect the implementation of the VFA program. George C Edward III (1980; 10-11) says: "The dispositions or attitudes of implementers is the third critical factor in our approach to the study of public policy implementation. If implementation is to proceed effectively, not only must implementers know what to do and have the capability to do it, but they must also desire to carry out a policy".

Commitment is closely related to the level of consistency between the implementation of the activities and the established guideline. The more suitable the implementation and the guideline, the higher the commitment will be. High motivation and seriousness in implementing a policy should be possessed by the implementers, not only depending on the organizations but also on their own selves. The data above showed that the Government of Kutai Kartanegara District has a high commitment to implement the VFA program. This is indicated by the significant increase of the VFA fund for the last two years. The implementers also show their high commitment because they are enthusiastic to implement the VFA program. However, the implementers still have low level of honesty because every year some cases are found in almost all of the villages.

\section{Review of SMITH's Theory:}

Smith's theory gives an emphasis on the importance of the capability of implementers in implementing policies (Putra 2001 : 92) (Parson 2008: 470-471) in addition to the importance of target groups, idealized policies, and social environment. However, this model does not explain the importance of control in the implementation of a program that is going to be completed.

As far as it is known, the nature of VFA activity is an intensive self-managed program so that deviations and irregularities performed by the technical implementers in the field are possible to occur. The data showed that the acts of dishonesty are found in almost every village with 3 or 4 cases, including the incompleteness of the administrative documents and receipts, problems related to the physical implementation which does not follow the RAB (Expenditure Budget Plan) and the difference in the use of fund.

All of the deviations or irregularities found by the district inspectorate and the community as the external controlling institutions and also BPD and the sub-district assistantship team as the internal control are followed up by the village chiefs to make further corrections so that the VFA can run well.

The data above showed that the emphasis given on the capability of implementers does not guarantee that the implementation of the VFA program can be effective. Although the implementers have qualified capability, if it is not followed by high level of honesty and commitment, it will open a possibility for deviations and irregularities to occur. Therefore, control activity is very important in VFA program. (Hogwood and Lewis, 1986) (C. Shabbir Cheema in Dennis A. Rondinelli, in Nawawi, 2009 : 194), (Van Meter dan Van Horn, in Hill and Hupe, $2008: 46)$. 
This has proved that control variable and the capability of the implementers are equally important in implementing the VFA program. Therefore, the model of policy implementation of Smith's theory can be modified as follows.

Fig 5 : the modified model of policy implementation of Smith's theory

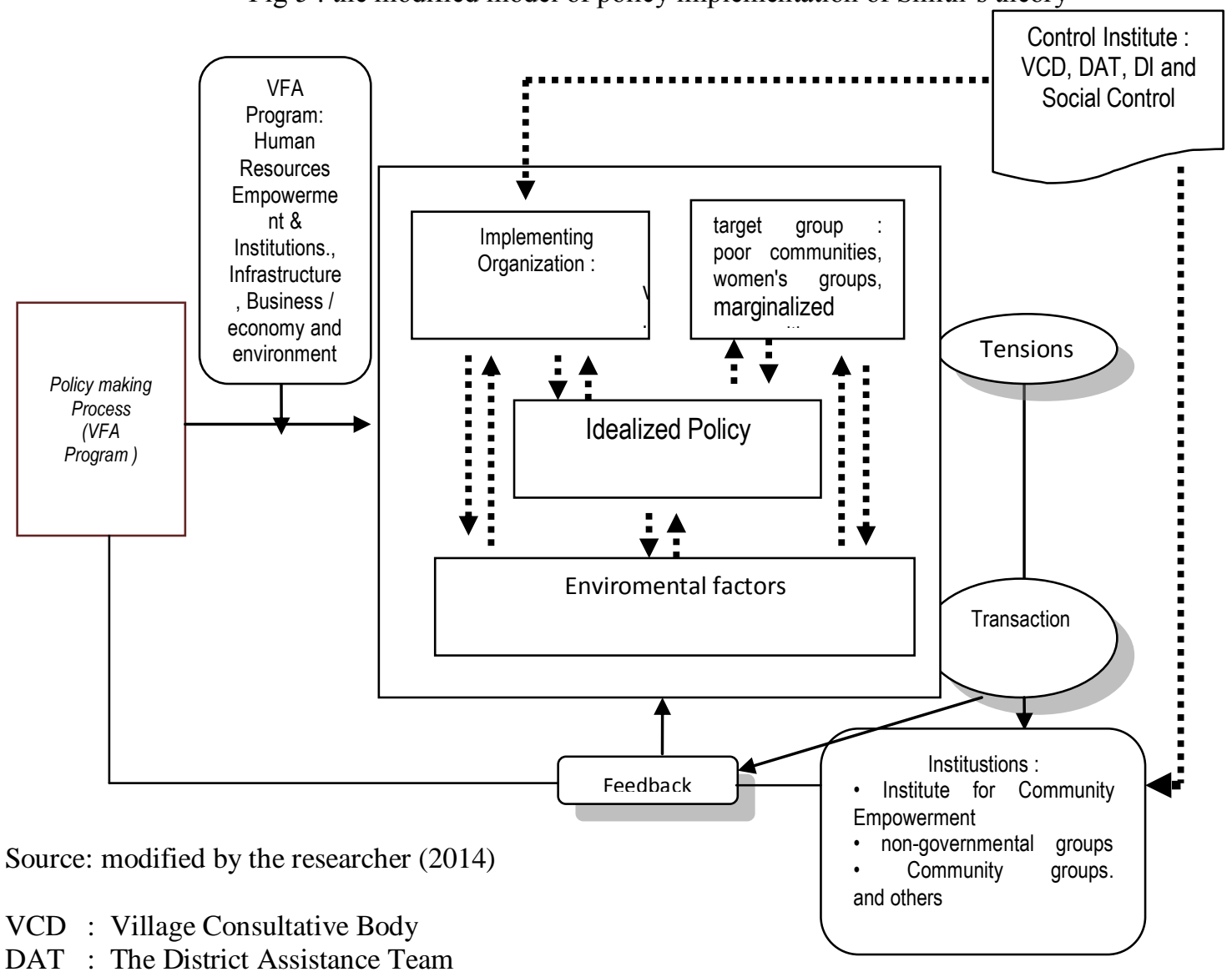

\section{Conclusion}

Based on the results of research and discussion that has been done then a conclusion can be drawn as follows:

- Control is very important. Control can affect the success of the VFA program because it can prevent the diishonesty of the implementers. Every form of deviations can corrected so that the VFA program will be run smoothly.

- There are external control agencies such as BPD (Village Consultative Body) and social control and internal monitoring agencies such as The District Assistance Team and the District Inspectorate

- The implementer capability is very important, too because having sufficient capability will help them to implement the VFA Program effectively.

- In researcher's findings the Implementor capability is still low.

- Commitment of implementers are quite high, but the honesty of the implementer is low

- The two variables (the implementer capability and control variable) are equally important because they can affect the succesfullnes of the policy implementation

\section{Suggestions}

This study has contributed to the theory of policy implementation raised by Smith, namely the importance of control variables that need to be taken into account in the implementation of a policy, therefore Smith's model of policy implementation needs to be modified. 


\section{Tex Books:}

\section{References}

[1]. Brinkerhoff, Derrick W and Benyamin L Crosby, 2002., Managing Policy Reform, Kumarin Press, Australia

[2]. Certo, Samuel C, 1994. Modern Management, Englewood Cliffs, New Jersey

[3]. Edward II, George, 1980, Implementing Public Policy, Congressional Quarterly Press, Washington DC

[4]. Ekowati, Mas Roro Lilik, 2009, Planning, Implementation and Evaluation of Policy or Program, Pustaka Caraka, Surakarta

[5]. Fischer, Frank dkk, 2007., Handbook of Public Policy Analisys, CRC Press London

[6]. Hidayat, Aceng, 200 Introduction to Institutional Economics 7., IPB, Bogor

[7]. Hill, Michael and Peter Hupe, 2008, Implementing Public Policy (Governance In Theory and In Practice), SAGE Publication, Singapore

[8]. Indiahono, Dwiyanto., 2009; Public Policy -Based Dynamic Policy Analisys, Gava Media, Yogyakarta.

[9]. James E Anderson,.., 1967, Public Policy Making New York, Rinehart and Wonston $2^{\text {nd }}$

[10]. Miles, Matthew B and a Michael Huberman, 1992, Qualitative Data Analysis, sage Publication Inc England

[11]. Nawawi, Ismail, 2009. Public Policy, Analysis, Theory and Practice Advocacy Strategy,PMN, Surabaya

[12]. Parsons, Wayne, 2008, Public Policy, Fajar Interpratama Offset, Jakarta

[13]. Poloma, Margaret M, 1994, contemporary sociology, PT. Raja Grafindo Persada, Jakarta

[14]. Putra, Fadillah, 2003, Critical Paradigms in Public Policy Studies, Pustaka Pelajar Yogyakarta.

[15]. Robbin, Stephen S, 1997, Organizational Behavior, Prentice-Hall International, USA

[16]. Smith, Thomas R, 1983., The Policy Implementation Process, Elservier Scientific Publishing Company, Amsterdam, Printed In Scotland

[17]. Subarsono, 2008; Public Policy Analysis, Cetakan Ke-2, Pustaka Pelajar, Jakarta

[18]. Winarno, Budi, Ph.D, 1989, Theories of Public Policy, Inter-University Center, Social Studies, Gadjah Mada University, Yogyakarta.

\section{Journals and Research Results}

[19]. Mahfudz, 2009, 10-22, Impact of ADD, Journal of Organization and Management, Volume 5, Number 1,Diponogoro University

[20]. Prasetyo, Budi, 2010, Orientation actor in the formulation of public policy, the Department of Political Science. Airlangga Orientation actor in the formulation of public policy, the Department of Political Science. Airlanggar University, Journal of Society, Culture and Politics University, Journal of Society, Culture and Politics

[21]. Soekanto., Soerjono, 2010, Supervision, Enforcement and Sanctions principles of Human Rights, FH UNNES, Semarang

\section{Regulation and Legislation}

[22]. Minister of Home Affairs Regulation No. 37 / 2007 on the Financial Management of the Village.

[23]. Circular Letter 140/161 / SJ.Th.2007. Minister of Home Affairs. General Guidelines for Financial Management of the Village,

[24]. Bapemas, 2009, the Bottom Planning, Kukar

[25]. Audit Reports Inspectorate. Kutai regency 2010

[26]. Regulation of Minister of Home Affairs Number 66, 2006 concerning Rural Development Plan

\section{Newspaper}

[27]. Tribun Newspaper, East Kalimantan, Monday, 11 May 2009

[28]. Pressing Deviations ADD, 2011.,: http; // www.bongkar .co.id / news /-law 26/1686-press-deviation-add.html (Wednesday, 06 July 2011) 